\title{
Extraordinary system of delusions and the social functioning - a case study
}

\author{
Nikodem Skoczeń ${ }^{1} \mathrm{AD}$, Sebastian Masternak ${ }^{1}{ }_{\mathrm{BE}}$, Marcin Olajossy ${ }^{1} \mathrm{DF}$
}

1. II Department of Psychiatry and Psychiatric Rehabilitation, Medical University of Lublin

\begin{abstract}
Schizophrenic psychoses are a heterogeneous group of diseases that affect about $1 \%$ of the world's population. The first symptoms of the disease usually manifest between ages 20 and 30. The diagnostic criteria for schizophrenia and its subtypes are characterized in detail in ICD-10. Diagnosis is based primarily on the presence of productive symptoms such as delusions or hallucinations occurring for at least one month which cannot be explained in another way. Schizophrenia is a disease which largely affects social functioning of patients, such as occupational performance, family life, interpersonal relationships or housing situation. Apart from the sociological aspect, social lives of schizophrenia sufferers are significantly impoverished due to cognitive impairment associated with improper functioning of NMDA receptors. The study describes a case of a patient suffering from paranoid schizophrenia which sheds light on the social functioning of this group of patients.
\end{abstract}

Keywords: delusions, social functioning

\section{Streszczenie}

Psychozy schizofreniczne to heterogenna grupa chorób, dotykająca około 1\% światowej populacji. Pierwsze objawy choroby występują zazwyczaj w wieku 20-30 lat. Kryteria rozpoznania schizofrenii, oraz jej postaci są dokładnie scharakteryzowana przez ICD-10. Rozpoznanie opiera się głównie na obecności objawów wytwórczych takich jak urojenia czy halucynacje występujących przez co najmniej jeden miesiąc i nie dających się wytłumaczyć w inny sposób. Schizofrenia jest chorobą w dużym stopniu obniżającą jakość funkcjonowania społecznego chorych, co objawia się na takich polach jak życie zawodowe, rodzinne, kontakty międzyludzkie czy sytuacja mieszkaniowa. Poza aspektem socjologicznym, ważną przyczyną zubożenia życia społecznego chorych wydają się być zaburzenia poznawcze związane z niewłaściwym funkcjonowaniem receptorów NMDA. W pracy przedstawiony został przypadek pacjenta chorującego na schizofrenię paranoidalną, na podstawie którego można wyciągnąć wnioski dotyczące społecznego funkcjonowania tej grupy chorych.

Słowa kluczowe: urojenia, funkcjonowanie społeczne

\section{Introduction}

Schizophrenic psychoses (synonym: schizophrenia) are a group of conditions with diverse clinical pictures and courses. The common denominator of these conditions is their similar symptomatology and prognosis. There are, however, more differences than similarities [1].

The criteria for schizophrenia are precisely defined by ICD-10. The diagnosis requires recognition of at least one of the characteristic signs and symptoms such as thought echo, thought insertion or withdrawal, thought broadcasting, delusions of control, influence, possession, or other absurd delusions (so-called "bizarre delusions"), and auditory hallucinations commenting on the patient or discussing him. The diagnosis can also be established on the basis of two less typical symptoms such as dissociation of speech, use of neologisms, overvalued ideas, catatonic behavior (excitement, stupor), and negative symptoms: apathy and blunted affect [2]. To diagnose schizophrenia, it is also necessary to exclude a manic or depressive episode and somatogenic factors such as diseases of the CNS or syndromes with secondary effects on the CNS.

As already mentioned, schizophrenia is a heterogeneous syndrome, so therefore ICD-10 distinguishes several forms of the disease: paranoid schizophrenia, which is dominated by delusions and hallucinations; hebephrenic schizophrenia with its characteristic flattened or inappropriate affect; residual subtype, in which negative symptoms predominate; as well as catatonic, undifferentiated, and undefined schizophrenia subtypes. Other schizophrenic disorders include postschizophrenic depression and simple schizophrenia, which is now rarely diagnosed [3]. The classification is still being developed, which is reflected in the revisions and additional caveats introduced in ICD-11, a final version of which is to be published this year. ICD-11 assumes, among other things, that hebephrenic schizophrenia should only be diagnosed in adolescents and young adults and that post-schizophrenic depression can be diagnosed if symptoms of schizophrenia are still present. The new classification will also define the criteria for undifferentiated schizophrenia [4]. In addition, it should be remembered that the boundaries of schizophrenia are not sharp and clear (though owing to the ICD and DSM criteria, diagnosis raises less and less doubt) and that there is the socalled borderline of schizophrenia, which links this disease with personality disorders, affective disorders, or psychoses with a different structure of delusions. 
The epidemiology of schizophrenia is difficult to describe by statistical methods, and therefore statisticians often come up with very different results. What may be a good point of reference here is McGrath and colleagues' 2008 metaanalysis of studies on the incidence of schizophrenia published in the years 1965-2002. It shows that the problem of schizophrenia affects about $0.5 \%$ of the world's population and lifetime morbid risk is about $0.7 \%$, i.e. less than traditionally assumed (1\%). Interestingly, men are characterized by a higher incidence of schizophrenia than women $(1.4 \times)$. The prevalence is also higher in urban settings compared with rural and suburban settings $(1.4 \times)$ and is significantly higher among migrants compared with native-born individuals (4.6x). On the other hand, no relationship was found between the risk of schizophrenia and economic status. The fact that schizophrenic patients more frequently belong to the less privileged social groups is explained by shifting of the patients to these groups. A similar explanation is given for the greater prevalence of schizophrenia among migrants. According to McGrath's meta-analysis, the standardized mortality ratio (SMR) calculated for overall mortality ("all-cause") is higher among schizophrenic patients (SMR 2.6), and the highest increase in the risk of death is associated with suicide (SMR 12.9) [5]. Schizophrenia is most often diagnosed in the third decade of life, and the mean age of the onset of symptoms is about 28 years for women and about 24 years for men [6].

\section{Case report}

The study describes a case of a patient suffering from paranoid schizophrenia which sheds light on the social functioning of this group of patients.

The patient (male, now aged 36 years) comes from a small town in eastern Poland. In high school, he was a good student and wanted to study law in the future. The first symptoms of the disease manifested in 1998, after he had graduated from high school. Coming back on a train from Radom, where he had submitted his application to the local University, he phoned his mother, telling her strange things. He said that he would reach his hometown from Lublin by taxi. The mother did not agree to this and went to collect him from the Lublin train station, but he wasn't there. The Police found him wandering around the city. The information in the patient's history indicates that he experienced pseudohallucinations - his mates "screamed in his head" to humiliate, frighten and destroy him mentally. The patient claims they did it "telepathically".

Over the following years, he studied journalism and political science at one of Lublin's universities, where he earned a bachelor's degree. He also began studying law, but failed to finish his studies because, despite treatment, his mental state deteriorated, which was reflected in his behavior - he disrupted lectures and even insulted his lecturers. During his studies, he participated in the activities of a Judaism club. During the holidays, he went to America, where his father lived, and during one of these visits he worked in a pastry shop run by a Jewish family, which affected the character of his later delusions.

For several years now, the patient has been suffering from delusions of descent and grandeur: he thinks he is the king of the Jews, and has a mission to fulfill for the Jewish people. He believes that his family are concealing their Jewish origin. The patient has on numerous occasions dressed in traditional Jewish clothes and has shown a keen interest in the history and culture of "his" people. He keeps living with his parents, is unemployed and is not very active. He mainly spends his time at the computer; he also plays basketball. He writes "for the drawer" but dreams of starting his own literary magazine devoted primarily to Jewish culture.

He was hospitalized four times: in 2003 in the youth department, and twice in 2014 and once in 2015 in the general psychiatric department.

He was first hospitalized in 2003 against his will - he did not feel ill. During his stay in hospital he had intense delusions; he thought he was a Jew, the savior of the world, the most important and the wisest person on Earth. As evidence of his Jewish descent, he cited the fact of being circumcised (he had subjected himself to this procedure when at high school). He dedicated a lot of time to the analysis of his surname - he looked for additional meanings and symbolism (following this track, he came to the conclusion that his family has a large business in Warsaw, he himself is the guardian of one of the towns in Poland, and that one of the large Asian nations is "his people "). His cognitive functions were impaired; he had primitive associations: when asked what the difference between a ball and an orange was, he said that "a ball is a football and an orange is a hand-orange". The patient complained of nightmares during which alleged enemies attacked his mind. He showed emotional instability and had alternating spells of elevated and depressed mood. The patient was treated with clopenthixol, perphenazine (up to 42 $\mathrm{mg} / \mathrm{d}$ ), levomepromazin (up to $75 \mathrm{mg} / \mathrm{d}$ ), and olanzapine (50 $\mathrm{mg} / \mathrm{d}$ ). He failed to achieve full remission.

In February 2014, he was admitted to the general psychiatry ward without his consent, brought by an ambulance as an urgent case. The patient was placed in hospital because of his verbal and physical aggression towards his family. While in the ward, he was found to have thought broadcasting and grandiose delusions as well as blunted affect. He spoke in an illogical way and suffered from insomnia and severe tension. Initially, the patient was very uncooperative - he refused to take medication, but after several days of hospitalization he gave his consent to treatment in the presence of a district court judge. In the ward, he received intensive treatment with risperidone tablets (up to $6 \mathrm{mg} / \mathrm{d}$ ), an extended-release suspension of risperidone (37.5 $\mathrm{mg}$, then $50 \mathrm{mg})$, levomepromazin (up to $50 \mathrm{mg} / \mathrm{d}$ ), chlorprothixen (up to $50 \mathrm{mg} / \mathrm{d}$ ), and a single dose of zuklopenthiksol (50 mg). 
The treatment resulted in partial recovery, and after about 5 weeks of hospitalization the patient was discharged home with instructions for self-administration of the following medications: risperidone $4 \mathrm{mg} / \mathrm{d}$, chlorprothixene $50 \mathrm{mg} / \mathrm{d}$, levomepromazine $50 \mathrm{mg} / \mathrm{d}$ and risperidone in an extendedrelease form every 14 days. The patient did not become fully critical of the symptoms of his disease. During treatment, the patient had a fasting blood glucose level of around $100 \mathrm{mg} / \mathrm{dl}$.

He was hospitalized again in July 2014. For two weeks prior to the admission to hospital, the patient had been unable to sleep, had had suicidal thoughts, had exhibited aggressive behavior and had been very agitated, also sexually. He had danced in front of his house, singing Hebrew songs; he also tried to have a sexual intercourse with his mother. On admission, he had grandiose and persecutory delusions: "Doctors are the police, I'm tsar". He had irrational ideas and delusions of thought insertion and broadcasting. However, he dissimulated the symptoms of the disease and did not consider himself a sick person. He did not feel the need for treatment and refused to cooperate with the hospital staff. After a long stay in hospital and inefficient treatment with several neuroleptics, his condition improved after clozapine was incorporated into the regimen (up to $600 \mathrm{mg} / \mathrm{d}$ ). Laboratory tests twice demonstrated elevated blood glucose levels of above $126 \mathrm{mg} / \mathrm{dL}$ (136 and $151 \mathrm{mg} / \mathrm{dL}$ ), which was a basis for diagnosing diabetes. The tests also demonstrated the presence of ketone bodies in the urine. Abnormal carbohydrate metabolism in the patient may have been associated with the chronic use of clozapine. The patient also had elevated levels of CK (up to $537 \mathrm{U} / \mathrm{l})$, and ultrasonography revealed enlargement of the liver (178 $\mathrm{mm}$ ) and hepatic steatosis as well as splenomegaly (143 mm), enlargement of the left kidney (134 mm), and deposits in the gallbladder. While in hospital, the patient was treated with risperidone (up to $2 \mathrm{mg}$ ), risperidone in an extended-release form (50 mg), haloperidol (up to $5 \mathrm{mg}$ ), levomepromazin (up to $75 \mathrm{mg}$ ), zuclopenthixol in an extended-release form (50 mg), olanzapine (up to $20 \mathrm{mg}$ ), chlorprothixen (up to $200 \mathrm{mg}$ ), clozapine (up to $600 \mathrm{mg} /$ day) and sodium valproate (up to $1200 \mathrm{mg}$ ). He was discharged home with instructions to take medications (clozapine, risperidone and valproate) and have regular tests done: a complete blood count with differential (once a month) and lipid profile and glucose tests (once every three months).

The last known hospitalization occurred at the turn of October and November 2015. Since the beginning of September 2015, the mental state of the patient had deteriorated: the patient experienced delusions of grandeur believing himself to be king of the Jews, children, Warsaw and the European Union, as well as the best playmaker in the world (the patient had for many years actively participated in basketball training sessions). He expressed delusions of descent: he considered himself to be a Jew, at the same time feeling he was a Roman; he also had persecutory delusions: he feared Arabs might steal his body, he believed that Hamas was hunting for him. He felt he had a mission to complete (he had to save the Jewish people). He interpreted reality in delusional terms; he claimed that God gave him great power so that he could send earthquakes and floods. He felt someone or something was planting thoughts in his mind (thought insertion); the messages "reached" him, among others, from his headgear. He did not feel ill, but he took his medications, believing that they "boosted his power". He claimed that he was in hospital for a checkup. He was in an elevated mood ("the sun is shining brighter"), denied having had any suicidal thoughts, and did not admit to aggressive behavior. When talked to, he was distracted and incoherent, but quite accommodating. While in the ward he felt good and thought he was surrounded by good people. During hospitalization, the patient was granted passes home, during which he functioned well. His parents did not report any reservations about his behavior. During hospitalization, the patient received clozapine at a maximum dose of $600 \mathrm{mg} / \mathrm{d}$, valproate at a dose of $1000 \mathrm{mg} / \mathrm{d}$, and an oral solution of risperidone up to $4 \mathrm{mg} / \mathrm{d}$. In the meantime, the patient was given one injection of an extended-release solution of risperidone at a dose of $50 \mathrm{mg}$. The patient also received flupenthixol at doses up to $6 \mathrm{mg} / \mathrm{d}$ (oral form) and after completion of treatment with risperidone, he also received injections of an extended release solution of flupenthixol at doses up to $40 \mathrm{mg} / \mathrm{d}$. At the time of hospitalization, partial recovery of mental health was achieved. The patient, however, did not become fully critical of the symptoms of his disease. On discharge, the patient showed no acute productive symptoms. The patient was instructed to continue treatment at the outpatient unit and to take medications: clozapine $550 \mathrm{mg} / \mathrm{d}$, extended release solution of flupenthixol $40 \mathrm{mg}$ IM every 2 weeks, sodium valproate $1000 \mathrm{mg} / \mathrm{d}$, levomepromazin $50 \mathrm{mg} / \mathrm{d}$, and hydroxyzine $50 \mathrm{mg} / \mathrm{d}$. Moreover, the patient was notified of the necessity to have a complete blood count with differential done once a month, and once every three months to assess indicators of liver function and markers of metabolic syndrome, such as AST, ALT, total bilirubin, total cholesterol, LDL, HDL, triglycerides, waist circumference, blood pressure, and blood glucose. It was also recommended that the patient have an EEG performed once a year.

Currently (December 2015) the patient is feeling well. In his mother's opinion, his condition is the best since the first hospitalization in 2014. The severity of the patient's psychotic symptoms, especially delusions of descent, has subsided. His mood and psychomotor drive have stabilized; the patient is relaxed and cooperates in his treatment. Once a week, he participates in basketball training sessions in a sports club. According to his mother, he does this with great commitment. In the near future, the patient will attend occupational therapy workshops offered by a community care center. Although the patient's condition has visibly improved, his parents are apprehensive about his future. They are particularly worried 
that when they grow old, they will not be able to take care of their adult child. They expect that the activities offered by the community care center will give him a chance for greater independence, and thus a safer future.

\section{Discussion}

One of the most important aspects of schizophrenia is the social functioning of the patients. The signs and symptoms of the disease make it difficult or impossible for patients to properly fulfil their life roles, which may lead to occupational, family and interpersonal problems. One of the authors who have set themselves the goal of describing how the patients function in the long term is Professor Andrzej Cechnicki. His follow-up study of the functioning of schizophrenic patients had been conducted since the mid-1980s in Kraków, on a group of 80 people. The study covered 20 years of treatment subsequent to the first psychiatric hospitalization. The mean age of the patients at the start of treatment was 27 years. Despite some defects that the study has been criticized for, such as an unusual patient education structure or the fact that some of the patients were excluded in the course of the study, Cechnicki's analysis remains a valuable source of knowledge.

A first, very important aspect of patient functioning is the ability of the patients to take up a job. In Ciechnicki's cohort, the proportion of professionally active patients was $88 \%$ before the first hospitalization, but unfortunately that number decreased in each period analyzed; for example, after the third year of treatment, only $66 \%$ of the patients had jobs, and after 20 -years, only $31 \%$ were professionally active, with some of the patients being employed in the protected job market. Quite predictably, job loss among the subjects was mostly caused by their poor mental condition (41\% of cases). What one should, however, also take into account is the fact that at the beginning of the study, the patients worked in a system governed by the principles of centrally planned economy, in which the state guaranteed a workplace to everyone. This notwithstanding, the percentage of the patients who had a job consistently decreased in the subsequent periods (admittedly, with varying dynamics) both in the period of socialism and capitalism.

Schizophrenia also has an adverse effect on interpersonal relationships, but the influence is not as clear as in the case of employment. While in the third year of treatment, $77 \%$ of the patients reported having satisfactory social relationships, not limited to the immediate family, after 20 years of treatment, this proportion dropped to $62 \%$. The remaining $38 \%$ of the patients were only in contact with their families and other patients. Somewhat surprisingly, the number of marriages entered into in the course of the disease increased with time. At the beginning of treatment, $34 \%$ of the patients were married, and after 20 years $47 \%$ had a spouse while $13 \%$ were divorced. When it comes to the housing situation, $66 \%$ of the patients after 20 years of treatment had their own independent households and were largely inde- pendent of their parents. Before the first hospitalization, this proportion was $37 \%$ [7].

The patient discussed in the present study was hospitalized for the first time 12 years ago. He is an example of a patient whose social functioning is heavily affected by the disease. He is unemployed, similarly to $62 \%$ of Cechnicki's patients after 12 years from the first hospitalization. He shows a willingness to work (start a magazine), but has for years been unable to carry out his plans. The patient still lives with his parents and is a bachelor, which places him in a worse position than that of the majority of patients: Cechnicki's analysis demonstrates that after 12 years of being ill, $69 \%$ of schizophrenia sufferers are more or less independent in terms of housing, and 50\% lead married lives (10\% are divorced). The patient discussed here feels the need to start a family, but with such chronic and intense psychoses his chances of doing so are very slim. He undoubtedly feels sexual impulses, but is unable to channel them in a conventional, socially acceptable way, as borne out by his attempt to have intercourse with his own mother.

At this point, the question arises why people who functioned well prior to the onset of the disease, lose their jobs and the ability to start a family and have satisfactory social relationships? Certainly, a great role here is played by the fact that healthy individuals stigmatize schizophrenia sufferers out of both resentment and fear. Obviously, there exist various sociological mechanisms that push patients to the margins of social life. It seems worth, however, to consider the neurological aspect of the problem involving the loss of cognitive function caused by the disease itself.

Cognitive deficits in schizophrenia include such problems as decreased processing speed, attentional impairments, impaired problem solving skills and word comprehension, and loss of the ability to learn effectively. Undoubtedly, these elements are indispensable for fulfilling social roles, both on a professional and personal level. Such impairments, of moderate to severe intensity, are observed in approximately $60 \%$ of patients with schizophrenia [8]. Research conducted by Hoff demonstrates that the first signs of cognitive impairment in these patients can be observed 3 to 4 years before the first hospitalization [9].

It is currently believed, that cognitive deficits in schizophrenic patients are chiefly due to dysfunctions of NMDA receptors. NMDA receptors are critical for synaptic transmission, the process of synapse formation and cognitive functioning. In schizophrenic patients, metaplasticity of these receptors, i.e. disturbances in their activation, are observed. The disturbances include both hindered and facilitated activation of NMDA receptors. Hindered activation leads to impairments of information processing in neural circuits, causing cognitive impairment. A reverse phenomenon - too easy receptor activation leads to excitotoxicity and neuronal damage. As a result of the toxic process, brain volume decreases during the 
course of the disease, which also results in impaired cognitive function. This process also leads to a decrease in the number of receptors which are drug targets. The latter phenomenon may provide explanation for the decline in the effectiveness of treatment with neuroleptics in successive courses of treatment and the phenomenon of drug resistance.

Negative symptoms of schizophrenia, also known as deficit symptoms, are a large and important group of symptoms associated with limitation of a variety of mental activities including impoverished form and content of thinking, reduced motor, impulsive and emotional activity as well as reduced emotional reactivity. Diagnostic assessment of this type of symptoms poses many difficulties because of the need to differentiate primary deficits caused by the disease from secondary deficits related to the effects of medications, environmental influences, and similar symptoms of other disorders, such as depression or minimally symptomatic stupor.

Unfortunately, people suffering from schizophrenia are still rarely active participants of the labor market, and they often find it extremely difficult to function in social networks [10]. There is evidence that deficits in social functioning in patients with schizophrenia are closely associated with negative symptoms of schizophrenia and that along with this type of symptoms they can lead to the worsening of the quality of life $[11,12]$. The low frequency of social interactions entails low participation in social networks. This problem in connection with the negative symptoms of schizophrenia should be an important area of therapeutic intervention [13].

An analysis of data collected in a study of a large group of European patients suffering from schizophrenia has shown that impairment of social interactions is a good predictor of the occurrence of other negative symptoms, worse psychosocial functioning and poorer quality of life. The data point to a great need for therapeutic interventions aimed at encouraging patients to use social support systems.

It seems that even an effective treatment of negative and productive symptoms cannot restore the patient's cognitive functions to the level they had before the onset of the disease [14]. The process of functional degradation of the nervous system can, however, be mitigated by administration of relapse-preventing neuroleptics and rapid treatment of psychoses [15]. The above-mentioned facts show that one of the key things that need to be done to maintain a patient's social functioning at a stable level, is to prevent the progression of cognitive deficits by keeping the patient in a state of remission.

\section{Conclusion}

It can be concluded on the basis of the follow-up study discussed earlier in this paper that the case reported here is not entirely representative when viewed against a larger group of patients, whose social functioning is usually at a slightly higher level. Nevertheless, it allows one to observe a full gamut of impairments of quality of life that schizophrenia can bring with it. The patient's cognitive impairment has probably progressed to a level where there is a serious risk that he will never be able to assume all the typical life roles. However, every effort should be made to bring him out of psychosis and maintain in remission, because only then can he achieve at least partial improvement of his social functioning with the help of health care units such as the outpatient center he has been referred to.

\section{References:}

1. Pużyński S., Rybakowski J., Wciórka J. Psychiatria: Psychiatria Kliniczna, $2^{\text {nd }}$ edition Elsevier Urban \& Partner, Wrocław 2011: 195.

2. Klasyfikacja zaburzeń psychicznych i zaburzeń zachowania w ICD-10 badawcze kryteria diagnostyczne. Kraków-Warszawa; Uniwersyteckie Wydawnictwo Medyczne "Vesalius" Instytut Psychiatrii i Neurologii: 1998

3. Wright P., Stern J., Phelan M.: Psychiatria Sedno tom 2 Elsevier Urban \& Partner 2005: 260-262

4. Heitzman J. Klasyfikacja zaburzeń psychicznych - koncepcyjne założenia ICD-11. Psychiatr. Pol. 2011; 45(6): 941-950

5. McGrath J., Saha S., Chant D., Welham J.: Schizophrenia: A Concise Overview of Incidence, Prevalence, and Mortality. Epidemiol. Rev. (2008) 30 (1): 67-76.

6. Häfner H.: Das Rätsel Schizophrenie: Eine Krankheit wird entschlüsselt. 2. Aufl. München; C.H. Beck: 2001

7. Cechnicki A.: Schizofrenia - proces wielowymiarowy. Instytut Psychiatrii i Neurologii, Warszawa 2011: 117, 157-167.

8. Rund BR, Sundet K, Asbjørnsen A et al. Neuropsychological test profiles in schizophrenia and non-psychotic depression. Acta Psychiatr. Scand. 2006; 113: 350-359.

9. Hoff A.L., Svetina C., Shields G., et al. Ten year longitudinal study of neuropsychological functioning subsequent to a first episode of schizophrenia. Schizophr. Res. 2005; 78: 27-34.

10. Fleury M.J., Grenier G., Bamvita J.M., Tremblay J., Schmitz N., Caron J. Predictors of quality of life in a longitudinal study of users with severe mental disorders. Health Qual. Life Outcomes. 2013; 11: 92

11. Breier A., Schreiber J.L., Dyer J., Pickar D. National Institute of Mental Health longitudinal study of chronic schizophrenia. Prognosis and predictors of outcome. Arch. Gen. Psychiatry. 1991; 48(3): 239-46

12. Katschnig H. Schizophrenia and quality of life. Acta Psychiatr. Scand. Suppl. 2000; 407: 33-37

13. 13.Kirkpatrick B., Fenton W.S. Carpenter Jr. W.T., Marder S.R. The NIMH-MATRICS consensus statement on negative symptoms. Schizophr. Bull. 2006; 32(2): 214-219

14. Krzystanek M., Krupka-Matuszczyk I., Klasik A. Neurocognitive expression of hypofrontality in long term schizophrenia. Uehara $\mathrm{T}$ (red.) Psychiatric disorders - trends and development. InTech, Rijeka 2011, 93-106.

15. Krzystanek M., Piekarska-Bugiel K., Pałasz A., Martyniak E., KrupkaMatuszczyk I. Leczenie zaburzeń poznawczych - Święty Graal leczenia schizofrenii. Review of Clinical Neuropsychiatry. 2015; 7(1): 11-15.

\section{Correspondence address}

Nikodem Skoczeń, II Department of Psychiatry and Psychiatric Rehabilitation, Medical University of Lublin, ul. Głuska 1, 20-439 Lublin, e-mail: nikodem.skoczen@onet.pl

Otrzymano: 24.02 .2016

Zrecenzowano: 03.03.2016

Przyjęto do druku: 05.03.2016 